\title{
Using multivariate factor analysis to characterize the unbranched fatty acid profile in bovine rumen fluid
}

\author{
Uso del análisis multivariado factorial para caracterizar el perfil de ácidos grasos no ramificados en \\ fluido ruminal de bovinos
}

Uso da análise multivariada fatorial para caracterizar o perfil de ácidos graxos não ramificados em fluido ruminal de bovinos

Julián A C Vargas*.

Faculdade de Ciências Agrárias e Veterinárias, Departamento de Zootecnia, Universidade Estadual Paulista “Júlio de Mesquita Filho”, Jaboticabal, São Paulo 14884-900, Brazil.

(Recibido: 24 de noviembre de 2017; Aceptado: 26 de noviembre de 2018)

To cite this article:

Vargas JAC. Using multivariate factor analysis to characterize the unbranched fatty acid profile in bovine rumen fluid. Rev Colom Cienc Pecu 2019; 32(3):175-183. DOI: https://doi.org/10.17533/udea.rccp.v32n3a02

\footnotetext{
**Corresponding author: Via de Acesso Professor Paulo Donato Castelane, km 05, s/n, Vila Industrial, Jaboticabal - SP, Brazil. E-mail: jcfcav@gmail.com
} 


\begin{abstract}
Background: Multivariate factor analysis (MFA) could be used for analyzing the complex pattern of correlations among fatty acids (FAs) in the rumen. Objective: To investigate the potential use of MFA to extract information on unbranched FAs metabolism in bovine rumen fluid. Methods: A dataset containing 107 individual records of 26 unbranched FAs from two in vitro ruminal incubation studies was constructed. The MFA was performed using the SPSS (Statistical Package for the Social Sciences) software. Results: The MFA extracted four latent factors, accounting for $86.7 \%$ of the total variance. The first factor was positively associated with short (6:0), medium (8:0, 10:0, 12:0, 14:0, and 16:0), and long (17:0, 20:0, and 23:0) saturated FAs (SFAs), as well as with cis and trans monounsaturated FAs (MUFAs) from 14 to 16 carbon atoms (14:1$t 5,14: 1-c 9,15: 1-t 10,16: 1-c 9$, and 16:1-t9). The second factor was positively correlated with 18:0 and the majority of $c i s$ and trans MUFAs of 18 carbon atoms (18:1-t9, 18:1-t11, 18:1-c6, 18:1-c9, and 18:1-c11). The third factor was positively related to $18: 3-c 9, c 12, c 15$ and 18:2-t11,c15, and negatively to $18: 2-c 9, t 11$. The fourth factor was positively correlated with 18:1-t6 and 19:0; however, 19:0 was also negatively associated with the second factor. The 18:2-c9,c12 was negatively correlated with the second and third factors. Conclusion: Multivariate factor analysis (MFA) allowed the reduction of a large number of fatty acids in bovine ruminal fluid to a few latent factors with biological meaning.
\end{abstract}

Keywords: cattle; lipid profile; lipid metabolism; multivariate statistics; multivariate factor analysis; ruminant; ruminal fluid; unbranched fatty acids.

\title{
Resumen
}

Antecedentes: El análisis multivariado factorial (MFA) podría usarse para evaluar el complejo patrón de correlaciones entre ácidos grasos (FAs) en el rumen. Objetivo: Investigar el uso potencial del AMF para extraer información sobre el metabolismo de FAs no ramificados en fluido ruminal de bovinos. Métodos: Se construyó una base de datos conformada por 107 registros individuales de 26 FAs no ramificados, provenientes de dos estudios de incubación in vitro. El MFA se desarrolló usando el programa SPSS (Statistical Package for the Social Sciences). Resultados: El MFA extrajo cuatro factores latentes, cuantificando el $86.7 \%$ de la varianza total. El primer factor se correlacionó positivamente con FAs saturados (SFAs) de cadena corta (6:0), media $(8: 0,10: 0,12: 0,14: 0$ y 16:0) y larga (17:0, 20:0 y 23:0) como también con FAs monoinsaturados (MUFAs) de 14 a 16 átomos de carbono (14:1-t5, 14:1-c9, 15:1-t10, 16:1-c9 y 16:1-t9). El segundo factor se correlacionó positivamente con 18:0 y con la mayoría de MUFAs cis y trans de 18 átomos de carbono (18:1$t 9,18: 1-t 11,18: 1-c 6,18: 1-c 9$ y 18:1-c11). El tercer factor se correlacionó positivamente con 18:3-c9,c12,c15 y 18:2-t $t 1, c 15$ y negativamente con 18:2-c9,t11. El cuarto factor se correlacionó positivamente con 18:1-t6 y 19:0; sin embargo, 19:0 también se correlacionó negativamente con el segundo factor. El 18:2-c9,c12 se correlacionó negativamente con los factores segundo y tercero. Conclusión: El análisis multivariado factorial (MFA) permitió reducir el gran número de ácidos grasos del fluido ruminal a unos pocos factores latentes con significado biológico.

Palabras clave: ácidos grasos no ramificados; análisis multivariado factorial; estadística multivariada; liquido ruminal; ganado; perfil lípidico; metabolismo de lípidos; rumiante.

\section{Resumo}

Antecedentes: A análise multivariada fatorial (MFA) poderia ser aplicada na análise do padrão complexo de correlações entre ácidos graxos (FAs) no rúmen. Objetivo: Investigar o potencial de uso do MFA para extrair informação sobre o metabolismo de FAs não ramificados no fluido ruminal de bovinos. Métodos: Construiu-se um banco de dados formado por 107 registros individuais de 26 FAs não ramificados, oriundos de dois estudos de incubação in vitro. A MFA foi desenvolvida usando o programa SPSS (Statistical Package for the Social Sciences). Resultados: A MFA extraiu quatro fatores latentes, quantificando $86.7 \%$ da variância total. O primeiro fator correlacionou-se positivamente com FAs saturados (SFAs) de cadeia curta (6:0), meia $(8: 0,10: 0,12: 0,14: 0$ e 16:0) e longa (17:0, 20:0 e 23:0) bem como com os FAs monoinsaturados (MUFAs) de 14 a 16 átomos de carbono (14:1-t5, 14:1-c9, 15:1-t10, 16:1-c9 y 16:1-t9). O segundo fator correlacionou-se positivamente com 18:0 e com a maioria de MUFAs cis y trans de 18 átomos de carbono (18:1-t9, 18:1-t11, 18:1$c 6,18: 1-c 9$ e 18:1-c11). O terceiro fator correlacionou-se positivamente com 18:3-c9,c12,c15 e 18:2-t11,c15 e negativamente com 18:2-c9,t11. O quarto fator correlacionou-se positivamente com 18:1-t6 e 19:0; porém, 19:0 também se correlacionou negativamente com o segundo fator. O 18:2-c9,c12 se correlacionou negativamente 
com os fatores segundo e terceiro. Conclusão: A análise multivariada fatorial (MFA) permitiu reduzir um número grande de ácidos graxos no fluido ruminal a poucos fatores latentes com significado biológico.

Palavras-chave: ácidos graxos não ramificados; análise multivariada fatorial; estatística multivariada; fluido ruminal; gado; perfil lipídico; metabolismo de lipídeos; ruminante.

\section{Introduction}

The diversity of fatty acids (FAs) in ruminant meat and milk is mainly derived from ruminal dietary FA metabolism (Jenkins et al., 2008). Some FA classes, such as unbranched cis and trans isomers of 18:1, 18:2, and 18:3 FAs, are associated with biological activity in humans (Hur et al., 2017). Therefore, a better understanding of unbranched FA metabolism in the rumen may aid in designing nutritional strategies to enhance the quality of beef and milk.

A combination of gas chromatography and multivariate statistics may enable us to infer metabolic relations in the complex ruminal FA profile. Gas chromatography has greatly improved over the last 20 years, and it is now possible to get a detailed ruminal FA profile, including the detection and quantification of several positional and geometrical isomers of the 16:1, 18:1, 18:2, and 18:3 groups of unbranched FAs (Delmonte et al., 2012; Mele et al., 2016). Additionally, multivariate statistics offers different techniques that can capture the covariance structures of complex patterns of variables. One of these techniques is multivariate factor analysis (MFA), which allows to explain the maximum amount of (co) variance among the original variables (Snedecor and Cochran, 1989). This technique divides the total variance of a multivariate system into two components: the variance that all the variables share (i.e., communality) and the particular variance of each variable (i.e., uniqueness). The MFA has been used extensively to analyze the complex milk FA profile (Macciotta et al., 2004; Macciotta et al., 2015; Mele et al., 2016), to model milk composition (Todaro et al., 2005), and to study milk coagulation properties (Macciotta et al., 2012; Dadousis et al., 2018). However, to date, MFA has not been used to analyze the complex ruminal FA profile. Therefore, in this study we investigated the potential of using MFA to obtain information on unbranched FA metabolism in bovine rumen fluid.

\section{Materials and methods}

\section{Ethical considerations}

All procedures used across studies were approved by the Bioethics Committee of the Facultad de Medicina Veterinaria y de Zootecnia, Universidad Nacional de Colombia (Act 001 of 2010).

\section{Data collection}

A dataset containing 107 individual records from two ruminal in vitro incubation studies (Vargas et al., 2012; Vargas et al., 2018) was constructed (Table 1). The studies were conducted at the facilities of Universidad Nacional de Colombia (Bogotá Campus, Colombia). The dataset used was composed of 26 short, medium, and long unbranched saturated and unsaturated FAs (6:0; 8:0; 10:0; 12:0; 14:0; 14:1-t5; 14:1-c9; 15:1-t10; $16: 0 ; 16: 1-c 9 ; 16: 1-t 9 ; 17: 0 ; 18: 0 ; 18: 1-t 6 ; 18: 1-t 9$; 18:1-t11; 18:1-c6; 18:1-c9; 18:1-c11; 19:0; 18:2-c9,c12; $18: 2-t 11, c 15 ; 18: 2-c 9, t 11 ; 18: 3-c 9, c 12, c 15 ; 20: 0 ; 23: 0)$, expressed as grams per 100 grams of total FAs.

The concentrations of FAs in the incubation systems were determined using gas chromatography coupled to a flame ionization detector (GC-FID). Briefly, FAs in the incubation systems were extracted and methylated according to Garcés and Mancha (1993). Methylated FAs were quantified using a Shimadzu GC-2014 gas chromatograph (Shimadzu Manufacturing, Inc., Canby, OR, USA). The column was a fused silica capillary (Rt$2560,100 \mathrm{~m} \times 0.25 \mathrm{~mm}$ i.d. x $0.2 \mu \mathrm{m}$ film thickness; Restec $\AA$, Inc, Belefonte, PA, USA). Helium was used as the carrier gas. Detector and injector temperatures were 260 and $270{ }^{\circ} \mathrm{C}$, respectively, and the split ratio was 30:1. Oven temperature was $140^{\circ} \mathrm{C}$ for $5 \mathrm{~min}$, increased by 4 ${ }^{\circ} \mathrm{C} / \mathrm{min}$ to $220^{\circ} \mathrm{C}$, held for $5 \mathrm{~min}$, increased by $2.0^{\circ} \mathrm{C} /$ min to $240^{\circ} \mathrm{C}$, and held for $10 \mathrm{~min}$. The FAs in samples were identified by comparison of their retention times with those observed in commercial standards as $\mathrm{Nu}-$ Chek ${ }^{\circledR}$ Prep (Elysian, MN, USA), and quantified by direct comparison of the peak areas. 
Table 1. Descriptive statistics of bovine rumen fluid fatty acid profile (FAs; $\mathrm{n}=107$ ).

\begin{tabular}{|c|c|c|c|c|c|}
\hline $\begin{array}{c}\text { Fatty acid } \\
\text { (g/100 g of total } \\
\text { FAs) }\end{array}$ & Common name & Min & Max & Mean & SD \\
\hline $6: 0$ & capronic acid & 0.44 & 4.16 & 1.22 & 0.69 \\
\hline $8: 0$ & caprilic acid & 0.19 & 1.15 & 0.43 & 0.19 \\
\hline $10: 0$ & capric acid & 0.01 & 0.28 & 0.07 & 0.05 \\
\hline $12: 0$ & lauric acid & 0.02 & 0.28 & 0.10 & 0.05 \\
\hline $14: 0$ & miristic acid & 0.20 & 0.72 & 0.38 & 0.12 \\
\hline $14: 1-t 5$ & $\begin{array}{l}\text { transmiristelaidic } \\
\text { acid }\end{array}$ & 0.10 & 0.36 & 0.18 & 0.06 \\
\hline $14: 1-c 9$ & miristoleic acid & 0.07 & 0.34 & 0.15 & 0.06 \\
\hline $15: 1-t 10$ & $\begin{array}{l}\text { trans- } \\
\text { pentadecenoic } \\
\text { acid }\end{array}$ & 0.62 & 3.38 & 1.54 & 0.61 \\
\hline $16: 0$ & palmitic acid & 7.27 & 22.2 & 11.3 & 3.62 \\
\hline $16: 1-t 9$ & $\begin{array}{l}\text { palmitelaidic } \\
\text { acid }\end{array}$ & 0.00 & 0.10 & 0.04 & 0.02 \\
\hline $16: 1-c 9$ & palmitoleic acid & 0.13 & 0.38 & 0.21 & 0.06 \\
\hline $17: 0$ & $\begin{array}{l}\text { heptadecanoic } \\
\text { acid }\end{array}$ & 0.31 & 0.84 & 0.47 & 0.14 \\
\hline 18:0 & stearic acid & 12.6 & 44.9 & 24.2 & 7.25 \\
\hline $18: 1-t 6$ & Petroselaidic & 0.05 & 0.26 & 0.14 & 0.05 \\
\hline $18: 1-t 9$ & elaidic acid & 0.08 & 0.90 & 0.36 & 0.21 \\
\hline $18: 1-t 11$ & $\begin{array}{l}\text { transvaccenic } \\
\text { acid }\end{array}$ & 2.39 & 20.8 & 10.6 & 5.34 \\
\hline $18: 1-c 6$ & petroselinic acid & 0.26 & 3.23 & 1.10 & 0.63 \\
\hline $18: 1-c 9$ & oleic acid & 0.52 & 1.68 & 0.97 & 0.26 \\
\hline $18: 1-c 11$ & vaccenic acid & 0.12 & 0.50 & 0.25 & 0.09 \\
\hline 19:0 & $\begin{array}{l}\text { nonadecanoic } \\
\text { acid }\end{array}$ & 0.06 & 5.54 & 0.85 & 1.16 \\
\hline $18: 2-c 9, c 12$ & linoleic acid & 0.77 & 58.2 & 17.6 & 14.7 \\
\hline $18: 2-t 11, c 15$ & ND & 0.09 & 6.67 & 2.59 & 1.79 \\
\hline $18: 2-c 9, t 11$ & $\begin{array}{l}\text { conjugated } \\
\text { linoleic acid }\end{array}$ & 0.00 & 12.2 & 2.42 & 2.39 \\
\hline $18: 3-c 9, c 12, c 15$ & $\begin{array}{l}\text { alpha-linolenic } \\
\text { acid }\end{array}$ & 3.42 & 48.6 & 17.9 & 11.8 \\
\hline $20: 0$ & metil araquidic & 0.16 & 0.66 & 0.30 & 0.12 \\
\hline $23: 0$ & tricosanoic acid & 0.08 & 0.30 & 0.15 & 0.06 \\
\hline
\end{tabular}

Min = minimum; Max = maximum; SD = standard deviation; ND = common name is not defined in the literature; $c=c i s ; t=$ trans.

\section{Statistical analysis}

An MFA was performed using the IBM SPSS (Statistical Package for the Social Sciences; IBM Corp, 2013) Statistics software, version $22\left(\right.$ IBM $^{\circledR}$ Corporation, Armonk, NY, USA), to explore the metabolic relationships between unbranched FAs in bovine rumen fluid (Johnson and Wichern, 2014). The main aim of MFA is to explain the (co) variance of a system defined by n measured variables $\left(Y_{1}, \ldots, Y_{\mathrm{n}}\right)$ by deriving a smaller number $\mathrm{p}(\mathrm{p}<\mathrm{n})$ of latent unobservable variables $\left(X_{1}, \ldots, X_{\mathrm{p}}\right)$, named common latent factors. The MFA accepts that the variance of each original variable can be decomposed into its common (i.e., communality) and unique (i.e., uniqueness) components. The factor model decomposes the covariance matrix of the measured variables $(Q)$ as follows:

$$
\mathrm{Q}=\mathrm{AA}^{\prime}+\varphi,
$$

where $A A^{\prime}$ and $\varphi$ are the communality and the uniqueness (co) variance matrices, respectively (Snedecor and Cochran, 1989; Hair et al., 2014).

As stated in the (co) variance model, the measured variables can be represented as a combination of p unobservable common factors $(X)$ plus a unique variable $(e)$ :

$$
\begin{aligned}
& \mathrm{y}_{1}=\mathrm{a}_{11} \mathrm{X}_{1}+\ldots+\mathrm{a}_{1 \mathrm{p}} \mathrm{X}_{\mathrm{p}}+\mathrm{e}_{1} \\
& \mathrm{y}_{\mathrm{n}}=\mathrm{a}_{\mathrm{n} 1} \mathrm{X}_{1}+\ldots+\mathrm{a}_{\mathrm{np}} \mathrm{X}_{\mathrm{p}}+\mathrm{e}_{\mathrm{n}},
\end{aligned}
$$

Where $a$ are the loadings that quantify the correlation between the ith latent factor and the measured variable. Loadings are the elements of the $A$ matrix of the theoretical factor variance model.

The MFA was performed on the correlation matrix of 26 individual unbranched FAs. The number of factors to be extracted was based on their eigenvalue $(>1)$, their readability in terms of the relationship with the original variables, and the amount of variance explained. Factor readability was improved through a VARIMAX rotation. To extract the latent factors, a variable was considered to be associated with a specific latent factor if the absolute value of its correlation with the specific factor was greater than or equal to 0.5 (Mele et al., 2016). The suitability 
of the dataset used in MFA was further checked by calculating the Kaiser-Meyer-Olkin Measure of Sampling Adequacy (KMO), which determines the difference between Pearson and partial correlations (Hair et al., 2014).

\section{Results}

In this study, the KMO was $0.812(\mathrm{p}<0.01)$, close to the empirical threshold of 0.80 (Macciotta et al., 2012), which allowed to conclude that dataset used was suitable for MFA.

The overall patterns of the composition of ruminal FAs (Table 1) consisted of 11 saturated FAs (SFAs), 11 monounsaturated FAs (MUFAs), and 4 polyunsaturated FAs (PUFAs). The SFAs accounted for almost $42 \%$ of total FAs, MUFAs accounted for almost $42 \%$, and PUFAs were a minor part, only accounting for almost $16 \%$. Palmitic acid (16:0) and stearic acid (18:0) were the main SFAs, transvaccenic acid (18:1-t11) was the main MUFAs, and linoleic acid $(18: 2-c 9, c 12)$ and alpha-linolenic acid $(18: 3-c 9, c 12, c 15)$ were the main PUFAs.

The MFA was able to extract four latent factors from the 26 FAs quantified in the ruminal fluid
(Figure 1), accounting for about $86.7 \%$ of the total variance. The first latent factor accounted for the $46.3 \%$ of the total variance, and it was positively associated with short (6:0), medium (8:0, 10:0, 12:0, 14:0 and 16:0), and long (17:0, 20:0, and 23:0) SFAs, as well as with cis and trans MUFAs from 14 to 16 carbon atoms (14:1-t5, 14:1-c9, 15:1-t10, 16:1-c9, and 16:1-t9). Therefore, this factor was named "de novo FAs and $\Delta$ desaturase activity" (Table 2 ). The second latent factor explained $26.6 \%$ of the variance behind the first factor. It was named the "biohydrogenation (18:0 and MUFAs)", and was positively correlated with 18:0 and the majority of $c$ is and trans MUFAs of 18 carbon atoms $(18: 1-t 9,18: 1-t 11,18: 1-c 6,18: 1-c 9$, and 18:1-c11) (Table 2).

The third latent factor was named as "biohydrogenation (PUFAs)"; it accounted for $8.6 \%$ of the total variance and was positively related to $18: 3-c 9, c 12, c 15$ and 18:2-t11,c15, and negatively to $18: 2-c 9, t 11$ (Table 2). Finally, the fourth factor was named "novel pathway"; it explained $5.2 \%$ of the total variance and was positively correlated with 18:1-t6 and 19:0 (Table 2). However, 19:0 was also negatively associated with the second factor. The 18:2-c9,c12 was negatively correlated with the second and third factors.

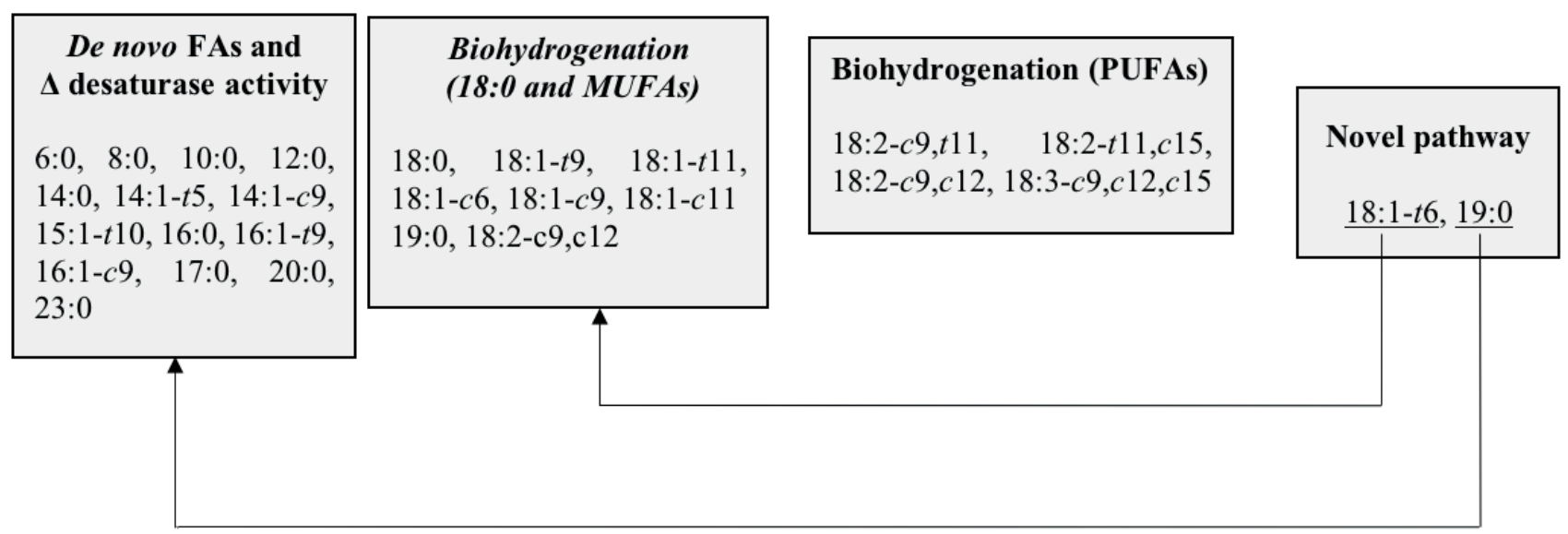

Figure 1. Metabolic groups of FAs in ruminal fluid and their interrelations derived from the multivariate factor analysis. FAs $=$ fatty acids, $c=$ cis, $t=$ trans. Despite 19:0 and 18:1-t6 were mainly associated with the fourth factor, 19:0 and 18:1-t6 had a second significant interrelation with the first and second factors, respectively, which were represented using arrows. 
Table 2. Rotated factor $(F)$ pattern and proposed factor name, for $F_{1}$ through $F_{4}$.

\begin{tabular}{|c|c|c|c|c|c|}
\hline Fatty acid & Common name & $\begin{array}{c}\mathrm{F}_{1} \\
\text { De novo FAs and } \\
\Delta \text { desaturase activity }\end{array}$ & $\begin{array}{c}\mathrm{F}_{2} \\
\text { Biohydrogenation } \\
\text { (18:0 and MUFAs) }\end{array}$ & $\begin{array}{c}\mathrm{F}_{3} \\
\text { Biohydrogenation } \\
\text { (PUFAs) }\end{array}$ & $\begin{array}{c}\mathrm{F}_{4} \\
\text { (Novel pathway) }\end{array}$ \\
\hline $6: 0$ & capronic acid & 0.854 & -0.244 & 0.144 & -0.038 \\
\hline $8: 0$ & caprilic acid & 0.947 & -0.141 & 0.031 & -0.078 \\
\hline 10:0 & capric acid & 0.786 & -0.378 & -0.010 & -0.160 \\
\hline $12: 0$ & lauric acid & 0.883 & -0.355 & 0.059 & 0.166 \\
\hline $14: 0$ & miristic acid & 0.939 & 0.135 & -0.023 & 0.138 \\
\hline $14: 1-t 5$ & transmiristelaidic acid & 0.891 & 0.331 & 0.072 & 0.084 \\
\hline $14: 1-c 9$ & miristoleic acid & 0.945 & 0.038 & 0.014 & 0.091 \\
\hline $15: 1-t 10$ & trans-pentadecenoic acid & 0.689 & 0.396 & 0.096 & -0.509 \\
\hline 16:0 & palmitic acid & 0.973 & 0.139 & 0.071 & 0.020 \\
\hline $16: 1-t 9$ & palmitelaidic acid & 0.836 & -0.232 & -0.006 & 0.107 \\
\hline $16: 1-c 9$ & palmitoleic acid & 0.837 & 0.464 & 0.038 & 0.029 \\
\hline $17: 0$ & heptadecanoic acid & 0.906 & 0.375 & 0.054 & 0.038 \\
\hline $18: 0$ & stearic acid & 0.351 & 0.897 & -0.064 & 0.164 \\
\hline $18: 1-t 6$ & Petroselaidic & 0.550 & 0.276 & -0.211 & 0.619 \\
\hline $18: 1-t 9$ & elaidic acid & -0.069 & 0.919 & -0.105 & 0.018 \\
\hline $18: 1-t 11$ & transvaccenic acid & -0.337 & 0.812 & -0.360 & -0.082 \\
\hline $18: 1-c 6$ & petroselinic acid & -0.273 & 0.919 & 0.026 & 0.061 \\
\hline $18: 1-c 9$ & oleic acid & 0.214 & 0.801 & 0.004 & -0.134 \\
\hline $18: 1-c 11$ & vaccenic acid & 0.263 & 0.848 & -0.001 & -0.397 \\
\hline 19:0 & nonadecanoic acid & 0.292 & -0.558 & 0.149 & 0.658 \\
\hline $18: 2-c 9, c 12$ & linoleic acid & -0.324 & -0.590 & -0.588 & -0.138 \\
\hline $18: 2-t 11, c 15$ & ND & -0.331 & 0.481 & 0.607 & -0.321 \\
\hline $18: 2-c 9, t 11$ & conjugated linoleic acid & -0.128 & 0.141 & -0.808 & 0.066 \\
\hline $18: 3-c 9, c 12, c 15$ & alpha-linolenic acid & 0.056 & -0.491 & 0.766 & 0.116 \\
\hline $20: 0$ & metil araquidic & 0.932 & -0.048 & -0.033 & 0.226 \\
\hline $23: 0$ & tricosanoic acid & 0.818 & 0.134 & 0.215 & 0.171 \\
\hline
\end{tabular}

FAs = fatty acids; MUFAs = monounsaturated FAs; PUFAs = polyunsaturated FAs; ND = common name is not defined by the literature; $c=c i s ; t=$ trans numbers in bold correspond to main correlations between a variable and a specific latent factor.

\section{Discussion}

The aim of this study was to investigate the potential of using MFA to extract information on unbranched FA metabolism in bovine rumen fluid. The results suggested that, unbranched ruminal FAs could be categorized under four latent factors with metabolic significance. This implies that multivariate factor analysis could be applied to studying FA metabolism in the rumen.

The results revealed that 16:0 and 18:0 were the most abundant SFAs in ruminal fluid. These SFAs are the most predominant FAs in ruminal bacteria and protozoa (Jenkins et al., 2008). This is in accordance with Or-Rashid et al. (2007), who revealed that 
$16: 0$ content was $74 \%$ greater in the protozoal FAs than in the bacterial FAs, whereas bacteria had 2.25-times greater 18:0 content than protozoa. Among MUFAs, 18:1- $t 11$ was the main FA. This was expected because 18:2-c9,c12 and 18:3-c9,c12,c15 tend to be mainly converted into 18:1-t11 during their ruminal biohydrogenation (Jenkins et al., 2008; Ferlay et al., 2017; Vargas et al., 2018). With respect to PUFAs, $18: 2-c 9, c 12$ and $18: 3-c 9, c 12, c 15$ were the main FAs. High concentrations of 18:2-c9,c12 and $18: 3-c 9, c 12, c 15$ were expected in ruminal fluid because the in vitro studies used to build dataset incubated pure 18:2-c9,c12 and 18:3-c9,c12,c15.

The MFA extracted four latent factors with biological meaning. The factor pattern (i.e., correlations between each factor and original variables) was easy to read. In particular, after examining the patterns across factors, we observed that many variables correlated highly with only one factor and poorly with others, showing correlation greater than or equal to 0.5 with one particular factor. This type of structure was an indicator of the suitability of multivariate factor analysis for examining the dataset used in this study (Snedecor and Cochran, 1989; Hair et al., 2014).

We observed that the first latent factor was positively associated with short, medium, and longSFAs, as well as with cis and trans MUFAs from 14 to 16 carbon atoms, naming this latent factor as " $d e$ novo FAs and $\Delta$ desaturase activity". Short, medium, and long-SFAs are endogenously synthesized by ruminal microorganisms from acetate and butyrate by the acetyl-CoA carboxylase and FA synthase enzyme (Emmanuel, 1974; Or-Rashid et al., 2007). Conversely, short and medium cis and trans MUFAs derive from $\Delta$ desaturase activities on the respective SFAs. Also, Ntambi et al. (1999) and Or-Rashid et al. (2007) demonstrated that bacteria and protozoa produce $\Delta 9$ and $\Delta 11$ desaturase enzymes, which produce MUFAs in the rumen. Therefore, MFA confirmed that these two groups of FAs (i.e., SFAs and short and medium-chain MUFAs) are metabolically linked under lipid ruminal metabolism, demonstrating that this statistical technique may be a valuable tool for analyzing the complex FA metabolism in the rumen.

A better understanding of the metabolic link between SFAs and MUFAs could help to enhance the physicochemical properties of milk. Considering that FA metabolism in the rumen significantly influences the milk FA profile (Jenkins et al., 2008, Hur et al., 2017), and milk fat fluidity is strongly affected by the relative abundance of SFAs (Mele et al., 2016), such understanding could be useful to design nutritional strategies for optimizing milk composition.

The 18:0 is considered as the main final product of 18:2-c9,c12 and 18:3-c9,c12,c15 ruminal biohydrogenation (Jenkins et al., 2008). However, Jouany et al. (2007), Shingfield et al. (2013), and Ferlay et al. (2017) demonstrated that these PUFAs are not completely biohydrogenated to 18:0, being interconverted in a great diversity of cis and trans MUFAs of 18 carbon atoms. Moreover, Or-Rashid et al. (2007) suggested that rumen protozoa have $\Delta 11$-desaturase activity, allowing conversion from 18:0 to 18:1-t11, and Kemp et al. (1984) and Ferlay et al. (2017) demonstrated that the ruminal fungus P. communis can dehydrogenate $18: 0$ to $18: 1-c 9$. Therefore, a metabolic link between 18:0, 18:1 cis and trans FAs, and PUFAs may be expected, as demonstrated by the second latent factor named as "Biohydrogenation (18:0 and MUFAs)", which was mainly composed by 18:0, a majority of cis and trans MUFAs of 18 carbon atoms, and of 18:2$c 9, c 12$.

The third latent factor was mainly composed by 18:2-c9, $c 12$ (which was also a representative FA of the second latent factor), 18:3-c9,c12,c15, 18:2-t11,c15, and $18: 2-c 9, t 11$. This suggests that the 18:2-c9,c12 could be a metabolic link between the second and third factors. This is as expected, considering that 18:2-c9,c12 and $18: 3-c 9, c 12, c 15$ have common metabolic intermediates (i.e., 18:1-t11 and 18:0) (Jenkins et al., 2008).

The 18:2-t11,c15 and 18:3-c9,c12,c15 presented a positive correlation with the third latent factor. This is because $18: 2-t 11, c 15$ is an intermediary key of 18:3-c9,c12,c15 biohydrogenation (Hur et al., 2017). Similarly, 18:2-c9,t11 and 18:2-c9,c12 presented a negative correlation with the third latent factor, due to $18: 2-c 9, t 11$ is an intermediary key of $18: 2-c 9, c 12$ biohydrogenation (Ferlay et al., 2017).

Unlike 18:0, 18:1, 18:2, and 18:3 FAs are interrelated during lipid metabolism in the rumen 
(Jenkins et al., 2008), MFA revealed that 18:0 and 18:1 cis and trans FAs need to be described by a factor (i.e., second factor), and 18:2 and 18:3 FAs need to be described by another factor (i.e., third factor). This suggests that these two groups of FAs may also be metabolized by independent biochemical pathways. This is in accordance with Harfoot and Hazlewood (1997), who suggested that despite ruminal FA biohydrogenation occurs by interaction between several microorganism species, there are microorganisms (i.e., Fusocillus) capable to completely biohydrogenate $18: 1-c 9$ and 18:2$c 9, c 12$ to $18: 0$, as well as $18: 3-c 9, c 12, c 15$ to $18: 1-c 15$ without interaction with another microbial species. In consequence, with the use of MFA, we could highlight the metabolic differences between these groups of FAs (18:0, MUFAs, and PUFAs) by extracting two different latent factors.

Finally, the fourth latent factor was mainly composed by 18:1-t6 and 19:0. Also, 19:0 was also highly correlated with the second factor. This suggests that the 18:1-t6 may be metabolically linked to $18: 1$ cis and trans FAs (second factor) using 19:0 as a potential intermediate. A metabolic relation between 18:1-t6 and 19:0 in PUFAs biohydrogenation has not been reported in the literature. However, Kim et al. (2005) demonstrated that 18:1-t11 was strongly associated with odd and branched-chain FAs during lipid ruminal metabolism. Therefore, a potential metabolic relation between 18:1-t6 and 19:0 FAs could be possible as well. Thus, MFA could be used in future studies to find potential novel ruminal biohydrogenation pathways.

We would expect a high correlation of 19:0 and 18:1-t6 to the first and second factors, respectively, considering that the first factor was mainly described by SFAs and the second factor was mainly composed by $18: 1$ cis and trans FAs. However, they constituted an independent factor. This may suggest that 19:0 and 18:1-t6 have different metabolic origins of their chemical families. This is in accordance with Harfoot and Hazlewood et al. (1997), who suggested that the metabolic origins of FAs during ruminal biohydrogenation may be affected by microbial populations and ruminal conditions. Moreover, the findings of Kemp et al. (1975) and Shingfield et al. (2013) demonstrated that several bacterial species are capable of independently producing specific SFAs, and 18:1 cis and trans FAs, not necessarily involving the general biohydrogenation process.

The data demonstrated that multivariate factor analysis has many positive outcomes when applied to a dataset derived from the analysis of bovine rumen fluid samples. A first positive outcome concerned the reduction of a great number of variables to a few latent factors with biological meaning. Second, the statistical approach classified groups of fatty acids with common metabolic origins or linked to defined metabolic pathways. Considering the recent emerging analytical techniques for determining novel fatty acids involved in ruminal metabolism, we suggest that multivariate factor analysis could be useful to design studies aiming to determine novel fatty acid metabolic pathways. Moreover, this information may aid in designing better nutritional strategies to optimize the nutritional quality of ruminant milk and fat.

\section{Acknowledgements}

I would like to thank professor Dr. Antonio Sergio Ferraudo from Sao Paulo State University for introducing me to the amazing world of multivariate statistics.

\section{Conflicts of interest}

The author declares he has no conflicts of interest with regard to the work presented in this report.

\section{References}

Dadousis C, Cipolat-Gotet C, Bittante G, Cecchinato A. Inferring genetic parameters on latent variables underlying milk yield and quality, protein composition, curd firmness and cheese-making traits in dairy cattle. Animal 2018; 12:224-231.

Delmonte P, Fardin-Kia AR, Kramer JKG, Mossoba MM, Sidisky L, Tyburczy C, Rader JI. Evaluation of highly polar ionic liquid gas chromatographic column for the determination of the fatty acids in milk fat. J Chromatogr A 2012; 1233:137-146.

Emmanuel B. On the origin of rumen protozoan fatty acids. Biochim Biophys Acta 1974; 337:404-413.

Ferlay A, Bernard L, Meynadier A, Malpuech-Brugère C. Production of trans and conjugated fatty acids in dairy ruminants 
and their putative effects on human health: A review. Biochimie 2017; In press.

Garcés R, Mancha M. One-step lipid extraction and fatty acid methyl esters preparation from fresh plant tissues. Anal Biochem 1993; 211:139-143.

Hair JF, Black WC, Babin BJ, Anderson RE. Multivariate data analysis: Pearson new international edition $7^{\text {th }}$ ed. Edinburg: Pearson Education Limited; 2014. p. 729.

Harfoot CC, Hazlewood GP. Lipid metabolism in the rumen. In: Hobson PN and Stewart DS, editors. The rumen microbial ecosystem $2^{\text {nd }}$ ed. London: Chapman and Hall; 1997. p.382-426.

Hur SJ, Kim HS, Bahk YY, Park Y. Overview of conjugated linoleic acid formation and accumulation in animal products. Livest Sci 2017; 195: 105-111.

IBM Corp. Released 2013. IBM SPSS Statistics for Windows, Version 22.0 Armonk, NY.

Jenkins TC, Wallace RJ, Moate PJ, Mosley EE. Board-Invited Review: Recent advances in biohydrogenation of unsaturated fatty acids within the rumen microbial ecosystem. J. Anim Sci 2008; 86:397-412.

Johnson RA, Wichern DW. Applied multivariate statistical analysis: Pearson new international edition $6^{\text {th }}$ ed. Edinburg: Pearson Education Limited; 2014. p. 765.

Jouany JP, Lassalas B, Doreau M, Glasser F. Dynamic features of the rumen metabolism of linoleic acid, linolenic acid and linseed WJ oil measured in vitro. Lipids 2007; 42:351-360.

Kemp P, Lander DJ, Orpin CG. The lipids of the rumen fungus Piromonas communis. J Gen Microbiol 1984; 130:27-37.

Kemp P, White RW, Lander DJ. The hydrogenation of insaturated fatty acids by five bacterial isolates from the sheep rumen, including a new species. J Gen Microbiol 1975; 90:100-114.

Kim EJ, Sanderson R, Dhanoa MS, Dewhurst RJ. Fatty Acid Profiles Associated with Microbial Colonization of Freshly Ingested Grass and Rumen Biohydrogenation. J Dairy Sci 2005; 88: $3220-3230$.
Macciotta NPP, Dimauro C, Null DJ, Gaspa G, Cellesi M, Cole JB. Dissection of genomic correlation matrices of US Holsteins using multivariate factor analysis. J Anim Breed Genet 2015; 132:9-20.

Macciotta, NPP, Cecchinato A, Mele M, Bittante G. Use of multivariate factor analysis to define new indicator variables for milk composition and coagulation properties in Brown Swiss cows. J Dairy Sci 2012; 95:7346-7354.

Macciotta NPP, Vicario D, Dimauro C, Cappio-Borlino A. A multivariate approach to modelling shapes of individual lactation curves in cattle. J Dairy Sci 2004; 87:1092-1098.

Mele M, Macciotta NPP, Cecchinato A, Conte G, Schiavon S, Bittante G. Multivariate factor analysis of detailed milk fatty acid profile: Effects of dairy system, feeding, herd, parity, and stage of lactation. J Dairy Sci 2016; 99:1-14.

Ntambi JM. Regulation of stearoyl-CoAdesaturase by polyunsaturated fatty acids and cholesterol. J Lipid Res 1999; 40:1549-1558.

Or-Rashid MM, Odongo NE, McBride BW. Fatty acid composition of ruminal bacteria and protozoa, with emphasis on conjugated linoleic acid, vaccenic acid, and odd-chain and branched-chain fatty acids. J Anim Sci 2007; 85:1228-1234.

Shingfield KJ, Bonnet M, Scollan ND. Recent developments in altering the fatty acid composition of ruminant-derived foods. Animal 2013; 7:132-162.

Snedecor GW, Cochran WG.Statistical methods, $8^{\text {th }}$ ed. Ames, Iowa: Iowa State University Press; 1989.

Todaro M, Scatassa M, Giaccone P. Multivariate factor analysis of Girgentana goat milk composition. Ital J Anim Sci 2005; 4:403-410.

Vargas JAC, Olivera M, Pabón M, Carulla J. Reduction of the biohydrogenation of linoleic and alpha-linolenic acid by addition of different proportions of eicosapentaenoic acid and docosahexaenoic acid. Rev Colomb Quím 2012; 41:395-408.

Vargas JAC, Olivera M, Ribeiro CVDM, Daza EE. In vitro rumen biohydrogenation kinetics of mixed linoleic and alfa-linolenic acids. Rev Colomb Cienc Pec 2018; 31:213-222. 